\title{
GEOECONOMIC STRATEGIES IN THE MODERN GLOBAL ECONOMIC SPACE
}

\author{
Oksana Gaiduchok \\ Department of International Business \\ Institute of International Relations \\ Taras Shevchenko National University of Kyiv \\ 60 Volodymyrska str., Ukraine, Kyiv, 01033 \\ o.gaiduchok@gmail.com
}

\begin{abstract}
In today's context, it is considered that with the reduction of the risk of military intervention, military security has come to the forefront and economic security has become a priority for the national interests of the country. As regional forces seek to expand markets, provide access to finance and the latest technologies, economic security has become a necessary component of regional forces' ability to spread their influence. The article is devoted to the study of national security and its relation to the functioning and formation of the geo-economic strategy in the conditions of globalization of the world, taking into account the national interests of countries. Each stage of the realization of the national interests of the country has its own assessment of its geopolitical, geostrategic and geoeconomic status, security threats and main carriers of these threats, mechanism of realization of national interests, resources, used for the purposes of such realization. Each of the stages provide its own assessment of the main definitions and categories of security, the main directions of geo-economic policy. The complex of current global mechanisms, aimed at ensuring the economic security of states from external threats, is investigated. The importance of forming the protective instruments of Ukraine's foreign economic policy is considered. The emphasis is placed on economic security, which is the foundation and material foundation of national security. The special place of economic security in the structure of national security is due to the fact that almost no type of security can be sufficiently implemented without economic security.
\end{abstract}

Keywords: economic interdependence, economic security, national security, financial security mechanisms, geoeconomic strategies.

DOI: $10.21303 / 2504-5571.2019 .001081$

\section{Introduction}

Contemporary debates, surrounding the creation of a new model of global regulation, are unfolding not only at numerous international venues, but also in academia and within the pages of special thematic publications. The rise of skepticism regarding today's dominant neoliberal doctrine is a source for rethinking the conceptual underpinnings of the theory of regulation of the global economy and the modern conceptual apparatus. It may be, that the intensity is shifting throughout the world economic system, as has been the case many times before. It will either end with the formation of a new model of global governance and the validation of «best practices» of regulation, or may be limited by the emergence of another dominant political and economic doctrine on the basis of the genesis of relations between numerous international regulators. Indeed, the existing mechanism, formed at the end of the last century in the form of the interaction of various elements, with a certain structure, purpose and general characteristics, is now the final model of regulation of world economic relations. It is based on a system of organizational and legal forms and methods of influence of interstate entities, institutions and instruments on the objects of the world economy.

The purpose of this model is to eliminate disparities in the development of individual elements of the mechanism on the basis of:

a) the multilevel nature of international regulation, which includes not only traditional state but also numerous non-state actors;

b) «chains» of decision-making practices: «state institutions, related to the activities of national governments, are informal, incl. public institutions - interstate and international agreements - decisions at the level of international organizations". It should be noted that in some areas of international relations, public-private partnerships, established in recent years, as mixed forms of international regulation, have a high potential in the development of proposals, participation of important management decisions from a number of problems and show fairly effective results. 
The mobility of the existing global infrastructure of international cooperation is compounded by the new challenges of economic globalization. The latter are the turbulence of a growing system of conflicts in the socio-economic and financial spheres at the national and regional levels, leading, on the one hand, to an increase in anti-globalist tendencies, and, on the other, to demands for a revision of the current world order and the restructuring of the international system of governance and global regulation through a search for new formats of economic partnership in the form of mega-regional trade agreements. The latter, in turn, changes the spheres of influence in the global economy and the emergence of alternative mechanisms and institutions of the international governance system (or transformation of existing ones).

Domestic and foreign scientists formed the informational and methodological basis of the article.

The first important articulation of the contemporary geopolitical implications of post-war economic trends was in the work of Paul Kennedy, which outlined the thesis of imperial overstretch and paid attention to financial and other economic constraints on national power [1].

The second major publication on the idea of «geoeconomics» was made by Edward Lüttwak, where he also defines geoeconomics as a science of methods of economic warfare and argued that states are the main actors in the global economic space [2].

Samuel Huntington spoke more straightforwardly and believed that geoeconomics was a continuation of war by other methods. He believed that the economic activity of a state is its main source of power [3].

Other well-known representatives of the American School of geoeconomics include Andrew Leishon and William Nester, who considered geoeconomics in the context of national/scientific interests $[4,5]$.

In Europe, the concept of geoeconomics was actively developed in Italy by General Carlo Jean, who argued that geoeconomics is based not only on logic, but also on the syntax of geopolitics and geostrategy [6]. A prominent representative of the French School of Geoeconomics is Jacques Attalli, former EBRD director who believed that the modern world is formed on the principles of geoeconomy [7].

Theoretical and empirical studies of this problem have been portrayed in the works of many leading scholars. This research takes a more practical approach to the concept of geoeconomics and its strategies while taking into account the findings of other prominent scholars.

The article aims to reveal the importance of the phenomenon of geoeconomics in the modern global space, to analyze the link between national security and national interests, to analyze the complications that arise due to conflicts of power and the impact they have on the international global order and on the formation of geoeconomic strategies.

The relevance of the analysis of the application of geoeconomic strategies by leading countries is that these strategies influence the formation of the new economic order, dictate its efficiency and functionality, and the prospects for the development of the global economy and its vectors.

\section{Materials and methods of research}

In the course of the study such general scientific methods as synthesis, grouping, historical and logical analysis, comparative analysis, systematic and scenario approach were applied. The author analyzes the modern practice of global regulations, the efficiency of such international organizations as NATO, IMF, WTO as well as the geoeconomic approaches and positions of the USA, EU, China, Russia and other countries. By using the aforementioned types of analysis there is an attempt to prove that the world is becoming more multipolar and that the global economic power is becoming more dispersed. Through an analysis of conflicts of power we determine the importance of geopolitical strategies as a means to protect a countries own interests and future.

\section{Results and discussions}

An analysis of the current practice of global regulation of the world economy shows that the agreements between the countries of the world community on the general principles of international regulation, the search for common interests between national and international entities 
remain constant, but in specific instances there are more and more differences. It is a common legal framework that must exist between key players, firm agreements and consensus, since it is the close partnership of different actors, reconciling their often diversified interests, that can bring global governance to a whole new level. In addition, the question of the scope of activities in the context of the «national sovereignty» of certain entities of global regulation in the processes of governing and regulating the world economy remains open.

At the same time, being aware of the poor efficiency of current national institutions, the unconditional need for international regulation and the usefulness of expanding its membership, many states, as the main subjects of global governance, are quite actively trying to maintain their sovereignty and regional «exclusivity» in decision-making in vital economic sectors. Much of the latter is due to the fact that the attempt to transform the IMF into a global anti-crisis regulator in recent years has not yet succeeded, resulting in a serious weakening of multilateral financial regulation. This is manifested in the IMF's insufficient ability to not only predict and prevent the emergence of financial crises, but also to promptly regulate the emerging financial market volatility. It is about creating an early warning system for financial crises and developing economic policy measures to reduce their risks. In addition, the Fund's development of new lending mechanisms and innovative solutions is lagging behind the real world financial processes $[8,9]$.

The accelerated creation of new regional markets in recent years, through the integration of previously weakly oriented national economies, as opposed to liberal WTO settings, and along with increased protectionism, have also led to increasing differences between the WTO participating countries on a number of issues. Suffice it to say that the effectiveness of this international organization is evident, for example, since 2008, more than 1.5 thousand laws, aimed at strengthening trade barriers, have been adopted by member states, and only $25 \%$ of them have been canceled [10]. Today, many postulates («one solution for all») and «rules of the game» (quality standards, norms, rules of regulation, etc.) require significant clarifications in the context of the correction of the WTO legal system, which is significantly behind the real economic reality. The slow progress of the creation of new mechanisms in the system of global regulation of economic uncertainty and political turbulence should be seen as a catalyst for the search by international regulators for new tools for global change management.

Indeed, the modern world economy is at the stage of forming a new multipolar world order, when the leading centers of the world economy - the USA, Western Europe and Japan - move to a higher level of post-industrial society, to a new technological base, a sixth technological level, based on nanotechnology. And although the new world order, evolved after the Second World War from bipolar to unipolar world, its essence and architecture have been preserved at the expense of the functioning of international financial and economic institutions within the UN, including the IMF, the WB, etc., which redistribute various elements of state sovereignty in favor of supranational and global regulators. As the prospects of global development in the medium term will determine the most economically and politically strong states and conglomerates of states with a stable value system and their own ideology, the contours of a new subjectivity of the world structure will gradually be formed.

On the one hand, combinations of diverse interests stimulate in the medium term the development of economically and politically interacting network communities. This largely motivates international regulators to emphasize the prospects for institutional development through the creation of a «new regulatory paradigm».

On the other hand, strengthening the position of the ever expanding universal international and regional organizations of participants with significant powers and resources requires an assessment, first, of the impact of the proposed international law on national rules and mechanisms of economic and legal regulation; second, scenarios of transformation of the system of global regulation and development of necessary and appropriate strategies of risk prevention and overcoming of imbalances of the global economy. Particularly noteworthy are the risks of a «domino effect» that cause global negative changes in the financial and economic system, including crisis situations. 
Modern geo-economic strategies as a symbiosis of political goals and long-term economic methods of redistributing resources through the creation of competitive regional economic conditions is a modification of the classical concept of «balance of power», but largely depends not on military confrontation and territorial expansion, but on the direction of international expansion, capital, geography of export-import flows of goods and technologies, redistribution of labor flows. Under certain conditions, there are even relapses of protectionism that have repeatedly turned into a subject of analysis by the WTO, the IMF, the World Bank and the G20 in the context of reconciling international trade and monetary policy. Yes, neo-mercantilist strategies, which are often resorted to by such new players in the world market as China, Brazil and India, are becoming a threat to the «axioms» and principles of international trade liberalization. These trends have led to the emergence of a new economic-oriented realism, which perceives the global economy as a «zero-sum geo-economic game» where the gains of one side are the loses of the other. In this regard, the issue of economic security of the country emerges as a priority, turning geo-economic calculations into an extremely important tool for regional development in the development of national economic policy [11].

In general, economic security is the foundation and material foundation of national security, meaning that almost no security can be sufficiently implemented without economic security. Until now, economic science has not defined the general concept of «national economic security», but in general it can be formulated as follows: a certain state of the economy and the institutions of power, which provides guaranteed protection of national interests, socially oriented development of the country and sufficient defense potential. More broadly, the essence of economic security is defined as a set of conditions and factors that ensure, first, the independence of the national economy, its stability and resilience to internal and external shocks of an economic and political nature, as well as the ability to neutralize potential threats. Secondly, the control of the state over national resources, the increase of production efficiency and quality of products, ensuring its competitiveness. Thirdly, the legislative base and stability of the society, protection against corruption components, a stable ability of the state to provide the population with resources and the ability to realize existing wealth for the further purpose of developing not only its own economy as a whole and its leading branches, but also other spheres of life. The fluctuation of the global economic environment and its impact on the national economy remains a serious problem, but no matter what the cause, economic security goes beyond the purely economic sphere. Thus, V. Pankov believes that economic security is not only the protection of national interests, but also the willingness and ability of state institutions to create mechanisms for the realization and protection of national interests in the development of the national economy [12]. C. Malkovich supports this view, but expands it to include the absence of dangers that could threaten economic stability and independence [13]. American scientists J. Kennan, W. Lippman, $\mathrm{K}$. Waltz have made a significant contribution to the development of the concept of «national interest», who argued that the problem of national security and its components cannot be considered only from the standpoint of interests, which exist at the moment - it should be closely linked to the needs and capabilities of the prospective period.

Currently, there are different classifications of national interests according to the following indicators:

1) depending on the duration of interests;

2) depending on the vital need to realize one or another interest;

3) depending on the area of interest;

4) depending on the level, at which the interests should be realized;

6) taking into account the sphere of social life to which interests belong [14].

In the US, for example, national interests are formally reflected in the National Security Strategy, adopted in 2015, and in which the key element is the economy. In addition, its components include: creating an international system in accordance with its own values and ideals; maintaining leadership in political, economic, technological and military spheres; deter any aggression that could threaten the security of the US and its allies; a strong position on the desire of other states to achieve military benefits; effectively confront the security threats to the United States, its citizens, 
and its interests; striving for political decisions on regional conflicts $[15,16]$. At the same time, the development of a competitive national economy, access to international markets, energy sources, natural resources, oceans and outer space is an important part of the US national security system. In the USA «vital interests» are crucial to the nation's survival, security and vitality.

Each stage of realization of national interests of the country is characterized by its own assessment, first of all, its geopolitical, geostrategic and geo-economic status, security threats and the main carriers of these threats, mechanisms of realization of national interests, resources, used for such realization; secondly, the main definitions and categories of security, main vectors and criteria of geo-economic policy. There is a close link between economic security and the system of national-state interests, which combines problems of economic potential and economic power of the state, geopolitical and geo-economic positions of the country in the modern world. At the same time, individual countries and non-governmental entities can at any time easily abandon geo-economic strategies and use military force against countries that have confronted them and inflict «preventive» harm on stronger opponents, at least temporarily. In a situation where industrialized countries find it increasingly difficult to justify the costs and human casualties of hostilities, President Vladimir Putin used Russian military intervention in Georgia, later in the Crimea, and finally in Syria, to restore Russia's status as a powerful player in international politics and get high ratings among the population. Russia is not the only example of military forces improving economic factors - in Iran and Pakistan in the Middle East and North Korea's nuclear intimidation strategy can be added to this list. If the success of military strategies continue to be repeated, it may cause even those nations that have resorted to economic instruments in foreign policy in recent years to rethink their strategy and attach much more importance to geopolitics, than for geoeconomics [17].

The modern multipolar and multi-conceptual world often densely leads to the fact that values are a source of controversy, not unity, not only globally, but also regionally and in the countries themselves. Value-based disputes manifest themselves differently, but they share common features: control and the role of the state [18]. Many political leaders believe that they have lost control and, in response, are trying to strengthen the state, generating a reconfiguration of the established system of international relations. At the national level, clashes occur between the state and the individual, the state and minorities, the state and the market, and because of technology. Globalization is affecting the country's foreign policy through multilateral rules and institutions, concepts of sovereignty and non-interference, migration and asylum, cyberspace change. In the context of growing geopolitical competition and the weakening of multilateral institutions, the debate over these pressing issues can lead to conflict. A fairly possible scenario is that at some point states will reject ideas of values and institutions that limit the autonomy of countries.

Settlement of international disputes is a matter of particular concern, especially in trade issues, with the «center of gravity» shifting from the West to Asia (for example, in 1950, US GDP was $27.2 \%$ of global GDP and China's $4.6 \%$, while in 2017 these figures were already $15.3 \%$ and $18.2 \%$ respectively) [19]. Nowadays, trade is an area, in which the negative and positive effects of the multipolar and multi-conceptual world are clearly traced. Thus, China-US trade relations have sharply deteriorated at the end of 2018, following the introduction of tariffs on steel and aluminum imports and Chinese products due to technological and intellectual property disputes. In fact, economic policy, which was considered a method of reducing geopolitical risks, is now used as a tool for strategic competition, and internal political factors outweigh the reality of compromise. Dynamic foreign direct investment indicators are also increasingly associated with geopolitical positioning: in 2017, the EC introduced methods of controlling non-European investment in the European Union, and in 2018, the US introduced a law to monitor investment in 27 sectors of the US economy. At some stage, with the worsening external investment climate, global economic growth can take the form of a «closed circle» where the economy and geopolitics will only stimulate each other. In doing so, the geo-economic vision creates new concepts of neo-imperialism, neo-mercantilism, hegemony and liberal institutionalism, and small and weak states will have to make painful decisions to secure investment for sustainable growth and strategic independence [20].

Today, the US, Brazil, South Africa, the EU, Japan, Germany, Russia are geo-economic regional leaders, but they all use radically different geo-economic strategies. With the reduction 
of the risk of military intervention, military security has come to the fore, and economic security has become a priority for the national interests of countries. While regional actors seek to expand markets, provide access to finance and the latest technologies, economic security is becoming a necessary component of their ability to spread their influence. The aforementioned actors are also geographical nodes of the regional economic networks, enabling them to control a significant amount of financial assets, that is, the economic and financial potential gives them the asymmetric economic power that they use to gain national advantages. In addition, the asymmetric interdependence that characterizes regional economic systems often gives regional actors disproportionate advantages.

The goal of harnessing economic potential, either geopolitically to achieve regional political leadership, or to accumulate wealth and reduce one's own vulnerability, is not always clearly pursued. When a regional economic potential is transformed into a factor of investment of significant economic resources in exchange for political influence and allies, without gaining economic benefits from these investments, the country's efforts to improve its geopolitical status or strengthen its regional leadership, as opposed to accumulating economic potential, are clearly followed. Alternatively, when a regional entity uses its economic potential to satisfy its own commercial interests rather than enhancing its leadership, it indicates that the motivation is economic rather than political. For decades, the United Kingdom, through its regional policy, has underlined the importance of its commercial interests in Europe, without wanting to spread its influence. The motivation for joining the EU was entirely economic and the country used its economic potential to promote more economically liberal ideas in line with national trade and investment interests.

\section{Conclussions}

The conflict of power has profound implications for the stability of nations. Often, stability is characterized by persistence, lack of turbulence, and resistance to change. Political systems differ in how stable they are. Totalitarian governments are perhaps the most stable, followed by established democracies, dictatorships, new regimes, and failed states. In the economy, stability enables social and economic development by attracting a critical mass of foreign direct investment, needed to pay for national development. From the point of view of war, stability is important because stable countries are more resilient to influence, leading to war, and stability makes military progress more resilient.

If countries do not stabilize, they typically need the assistance of a wide range of military, civilian, public, bilateral, multilateral, non-governmental and private sectors. In practice, this assistance focuses on three main elements: security, governance and the economy. All three are deeply dependent.

Security is a must. Without strong national security, good governance and economic foundations are not able to develop sustainably. Stable governance requires countries to manage their political, military, economic, social, legal, regulatory and judicial affairs. Economic elements of stability include the economic infrastructure, as well as the legal, regulatory and political environment necessary for economic growth.

In an era of force competition, the number of countries in the gray zone, between war and peace, will grow, drawing more and more of them into this confrontation. This will require greater attention to stability operations in these areas, both before and during conflicts. In the future, more and more countries will join this great competition. Conflicts will arise in countries, where they did not previously exist, and instability will increase. The use of a proxy will reduce the likelihood of direct conflicts of force, but disputes will escalate at a time when the world is getting smaller and conflicts - larger. Thus, determining the right geo-economic strategy is the key to successful foreign economic activity.

Each participating country must, in the new realities of globalization, develop its own geoeconomic strategy, as an adaptation to the new realities of globalization, or as a response to other countries' geoeconomic strategies. In this regard it is also of interest to research the formation of the new economic order. 


\section{References}

[1] Kennedy, P. (1987). The Rise and Fall of the Great Powers: Economic Change and to Military Conflict From 1500-2000. New York: Random House, 677.

[2] Luttwak, E. (1990). From Geopolitical to Geo-economics: Logic of Conflict, Grammar of Commerce. The National Interest, 20, 17-24.

[3] Huntington, S. P. (1993). Why International Primacy Matters. International Security, 17 (4), 68. doi: http://doi.org/10.2307/ 2539022

[4] Nester, W. (1995). International Relations: Geopolitical and Geoeconomic Conflict and Cooperation. Illinois: Harpercollins College Div.

[5] Leyshon, A. (2003). Alternative Economic Spaces. London: SAGE. doi: http://doi.org/10.4135/9781446220825

[6] Zhan, K., Savona, P. (1997). Geokonomika. Gospodstvo ekonomicheskogo prostranstva. Moscow: Ad Marginem, 207.

[7] Attalli, J. (1991). Line on the horizon.

[8] Maxie, J. (2017). The Elephant in the Room: US Needs A Geo-economic Strategy For Asia, Now. Available at: https://thediplomat.com/2017/02/the-elephant-in-the-room-us-needs-a-geo-economic-strategy-for-asia-now/

[9] Zarate, J. (2012). Playing a New Geoeconomic Game Juan Zarate. Global Forecast, 69-71. Available at: https://csis-prod.s3.amazonaws.com/s3fs-public/legacy_files/files/publication/120417_gf_zarate.pdf

[10] WTO World Trade Statistical Review (2019). Available at: https://www.wto.org/english/res_e/statis_e/wts2019_e/ wts2019_e.pdf

[11] Geoeconomics and Strategy (2018). Virginia, 24. Available at: https://www.canon-igs.org/event/report/180529_Goldstein_presentation.pdf.

[12] Pankov, V. (2011). Economic Security: Essence and Manifestations. International Affairs, 57 (1), $192-202$.

[13] Mijalković, S., Milošević, G. (2011) Correlation between Economic, Corporate and National Security. Megatrend Review, 8 (2), 437-454.

[14] Trade and Development Report 2018. Power, Platforms and the Free Trade Delusion. New York, Geneva, 162. Available at: https://unctad.org/en/PublicationsLibrary/tdr2018_en.pdf

[15] McInnis, K. J. (2018). The 2018 National Defense Strategy. Available at: https://fas.org/sgp/crs/natsec/IN10855.pdf

[16] Providing for the Common Defense The Assessment and Recommendations of the National Defense Strategy Commission (2018). Washington: US Institute of Peace, 116. Available at: https://www.usip.org/sites/default/files/2018-11/providing-for-the-common-defense.pdf

[17] Mair, S. From Geopolitics to Geoeconomics. Available at: https://deutschland-und-die-welt-2030.de/en/article/from-geopolitics-to-geoeconomics/

[18] The Global Risks Report 2019 (2019). World Economic Forum. In partnership with Marsh \& McLennan Companies and Zurich Insurance Group. Available at: http://www3.weforum.org/docs/WEF_Global_Risks_Report_2019.pdf

[19] Lewis, D. (2018) Beltand Road Interview Series: Don Lewison BRI's Legal Framework. Belt \& Road Advisory. Available at: https://beltandroad.ventures/beltandroadblog/2018/08/05/understanding-the-bri-legal-framework

[20] Wigell, M. (2015). Conceptualizing regional powers' geoeconomic strategies: neo-imperialism, neo-mercantilism, hegemony, and liberal institutionalism. Asia Europe Journal, 14 (2), 135-151. doi: http://doi.org/10.1007/s10308-015-0442-x 